\title{
Mastering digital transformation through business process management: Investigating alignments, goals, orchestration, and roles
}

\author{
Ana-Marija Stjepić ${ }^{1}$ (iD, Lucija Ivančić ${ }^{2}$ iD, \\ Dalia Suša Vugec ${ }^{3}$
}

\begin{abstract}
Both business process management and digital transformation are areas that have been a topic of interest for both academia and practice. Since digital transformation is the creation of new, innovative business models and/or change and improvement of the existing business model with the help of digital technologies, one could raise a question regarding the role which business process management plays in digital transformation. With the purpose of shedding some light on that, this paper presents a theoretical framework for observing the link between business process management and digital transformation. Moreover, the results of an extensive literature review and analysis with regards to the presented framework has been given. The results confirm the important role of business process management in digital transformation. However, the results also indicate the need for further research and a greater understanding of practice.
\end{abstract}

Keywords: digital transformation, business process management, digital economy, digital technology, digitalization, digitization, literature review

\section{INTRODUCTION}

Rapid development of technology, as well as many changes in the global market today, has led to the emergence of a new trend - digital transformation. As

1 Ana-Marija Stjepić, Ph.D. student, University of Zagreb, Faculty of Economics \& Business, Trg J.F. Kennedya 6, 10000 Zagreb, Croatia, e-mail: astjepic@efzg.hr (ORCID ID: https://orcid.org/0000-0002-3588-8447).

2 Lucija Ivančić, Ph.D. student, University of Zagreb, Faculty of Economics \& Business, Trg J.F. Kennedya 6, 10000 Zagreb, Croatia, e-mail: ljuros@efzg.hr (ORCID ID: https://orcid.org/0000-0003-0491-7230).

3 Dalia Suša Vugec, Ph.D. student, University of Zagreb, Faculty of Economics \& Business, Trg J.F. Kennedya 6, 10000 Zagreb, Croatia, e-mail: dsusa@efzg.hr (ORCID ID: https://orcid.org/0000-0002-4702-6000). 
stated in Tapscott (1997), digital economy opportunities can facilitate the creation of new business models. Besides, he also highlights the usage of digital technology for restructuring existing business processes and models (Tapscott, 1997). Similarly, Terrar (2015) indicates that a successful digital transformation process leads to the creation of new business models, as also pointed out in the digital transformation definition debate in the work of Henriette, Feki, and Boughzala, (2015). According to Pejić Bach, Spremić, and Suša Vugec (2018), digital transformation refers to the change of existing business models as well as to the creation of new ones by implementing and using digital technologies in the process. There are many drivers for digital transformations, such as advancement in technology, the appearance of new business models, changes in expectations of the customers, etc. (Valdez-de-Leon, 2016).

On the other hand, business process management is a well-established discipline, which has been studied by many researchers and implemented in practice all over the world (e.g., Škrinjar, Bosilj Vukšić, \& Indihar-Štemberger, 2008; Hernaus, Pejić Bach, \& Bosilj Vukšić, 2012; Buh, 2016). Business processes are the core of every organization, and therefore, their management is of great importance in practice. However, changes that are happening on the global market also influence changes within the organizations that have to adapt to new conditions as quickly as possible in order to prosper in the market. One of the ways they are able to follow the global trends is to make changes to their business processes. Therefore, the role of business process management in digital transformation should be investigated (Van Looy, 2018).

Considering all of the above, the main goal of this study is twofold. The first goal of the study is to present an overview of the available literature regarding the link between digital transformation and business process management. The second goal of this study is to set a theoretical framework regarding the role of business process management in digital transformation that could serve as a guideline for future research, as well as a guideline for practice when conducting digital transformation initiatives.

In order to achieve the stated goals of the paper, its structure is as follows. After the introduction, a literature review is given, presenting the main ideas behind business process management and digital transformation, as well as the background for investigating the link between two named scientific areas. Next, the research methods are described in terms of the search methods for the presented literature review and the research framework. The third part of the paper refers to the presentation and analysis of the results, while in the fourth part of the paper a short discussion is given. The paper ends with a conclusion, limitations of the study, and directions for future research. 


\section{LITERATURE REVIEW}

\section{Business process management}

Business process management is a field of research that has been the focus of researchers for numerous years, which does not come as a surprise given that business processes play a pivotal role within every organization. According to Reijers (2006), the basis of each organization is primarily business processes, not products or services, which is in line with the definition of business processes provided by Scheer and Nüttgens (2000, p. 376), who define it as "a procedure relevant for adding value to an organization." Having in mind the definitions of business processes, it is very important for the organization to monitor and manage their processes in an effective way. In addition, tools and techniques for managing business processes, as well as process models, are considered to be one of the most valuable organizational assets (Turetken \& Demirors, 2011; Alotaibi, 2016).

During the course of time, some authors have described business process management as a technical discipline focused on information technology (IT) with the purpose of process automation, analysis, and improvement (Zairi, 1997; Harmon, 2003). On the other side, other authors (e.g., DeToro \& McCabe, 1997; Harmon, 2007) presented business process management as a managerial discipline. However, in the last decade, the understanding of business process management has shifted from focusing on an IT or managerial aspect towards a multidisciplinary and holistic view of the discipline (Rosemann \& de Bruin, 2005; Grau \& Moorman, 2014; vom Brocke et al., 2014; Müller, Schmiedel, Gorbacheva, \& vom Brocke, 2014; Van Looy, 2017). According to Schmiedel, vom Brocke, and Recker (2013, p. 293), business process management is "a holistic management approach focused on organizational processes as opposed to organizational functions." Hammer $(2015$, p. 3 ) views it as "a comprehensive system for managing and transforming organizational operations." The holistic nature of business process management includes the measurement and improvement of business processes, as well as alignment with organizational strategy and goals (Bosilj Vukšić, Suša Vugec, \& Lovrić, 2017). If that alignment is successful, organizations can achieve better business results (Van Looy, 2017; Harmon, 2018).

Even though business process management has existed as a discipline over a long period of time, the interest of the practice for implementation and adoption of business process management is not decreasing. On the contrary, the latest research shows that the market for business process management is expected to grow between 2017 and 2023 at $14 \%$ of 
compound annual growth rate (Market Research Future, 2018), which confirms its relevance for organizations.

\section{Digital transformation}

In the process of the ongoing digital transformation efforts in organizations, the need for systematically defining the underlying management and organizational activities emerges. Hence, different authors provide different views on digital transformation. However, a common conceptual agreement is still missing, as also pointed out in the literature reviews by numerous authors (Bosilj Vukšić, Ivančić, \& Suša Vugec, 2018; Henriette et al., 2015; Reis, Amorim, Melão, \& Matos, 2018).

It is important to differentiate between the terms "digitization" and "digitalization." While "digitization" refers to changing from analog to digital (Gartner Inc, 2018a), "digitalization" refers to improving existing business models, creating new revenue, as well as value-adding opportunities with the help of digital technologies (Gartner Inc, 2018b). According to Bosilj Vukšić, Ivančić, and Suša Vugec (2018), this definitions ambiguity is commonly seen in digital transformation literature, indicating unfilled research space for systematically outlining digital transformation and its related concepts. According to Pejić Bach et al. (2018), digital technologies imply the usage of digital resources such as digital tools, algorithms, applications, and various technologies, and can be considered as the most important factor in the digital economy. Spremić (2017a) argues that digital technologies enable the efficient use of digital goods within a digital environment, aiming to create disruptive innovations that can be considered as "game changers" in the market. Digital technologies can bring many benefits to organizations in every industry, which is the main reason that more and more initiatives are being conducted, aiming to explore and exploit digital technologies (Matt, Hess, \& Benlian, 2015). Hence, the term "digitalization" is more suitable for explaining the impact of digital technologies on organizations in the process of digitally transforming, while the term "digitization" should be diminished from the digital transformation debate unless being properly used. For instance, "digitization" in digital transformation initiatives can be used in medical informatics research or interdisciplinary engineering fields, as it has been used properly ever since the beginnings of computerization (see for instance the adequate use in (Akos \& Tsui, 1996; Steinhubl \& Topol, 2015).

Similarly to the dissolution between the terms "digitization" and "digitalization" that was stated before, the necessity for a clear differentiation between "digitalization" and "digital transformation" needs to be repeated, since a misidentification of these terms is evident, as pointed out by Bosilj 
Vukšić et al. (2018). While "digitalization" has already been defined in the previous paragraph as the employment of new, digital technologies in organizations, such as cloud; augmented reality; robotics; and Big Data (Spremić, 2017a), "digital transformation" is a holistic concept that includes digital and other technologies, as well as organizational and strategic changes. Despite the occasional misidentification, a holistic definition of digital transformation is often stressed by numerous authors (e.g., Kane, Palmer, Philips, Kiron, \& Buckley, 2015; 2016). For instance, Reis et al. (2018) define digital transformation as "the use of new digital technologies that enables major business improvements and influences all aspects of customers' life." Henriette et al. (2015) refer to it in terms of "more than just a technological shift," but transformations having "an impact on the business models, the operational processes and the end-user experience." Digital transformation, according to the definition provided by Terrar (2015), is the process that an organization is going through when it makes a shift "from a legacy approach to new ways of working and thinking using digital, social, mobile, and emerging technologies." Conducting a digital transformation within an organization does not imply only the transformation of key business operations and processes, but changes in organizational structures, as well as in management concepts, ways of thinking and leading (Matt et al., 2015; Terrar, 2015). Francis (2018) summarizes five areas that are included in digital transformation, being: (i) a shift in thinking, (ii) changes in leadership, (iii) technology embracement, (iv) digitization of resources, and (v) innovation embracement. In order to lead their organizations towards successful digital transformation processes, management should encourage innovative thinking and digitization, leading to the creation of new business models (Terrar, 2015).

Moreover, Matt et al. (2015) present a framework for successful digital transformation consisting of four dimensions: (i) changes in value creation, (ii) structural changes, (iii) use of technologies and (iv) financial aspect, emphasizing the importance of the close alignment of the mentioned dimensions. On the other hand, Kontic and Vidicki (2018) argue that the main management focus should be on competitiveness, products and services, as well as on marketing, rather than on financing. Nevertheless, for conducting a successful digital transformation it is of great importance to develop a good and clear digital strategy. It is important to understand that digital strategy is not equal to IT strategy. As stated in McDonald (2012), IT strategy is mostly based on isolated technologies, while digital strategy includes the simultaneous use of several digital technologies, combines digital and physical resources, and is concentrated on specific business outcomes (McDonald, 2012; Spremić, 2017a). However, it is crucial to achieve and 
maintain alignment between IT strategy, digital transformation strategy, and all other organizational strategies (Matt et al., 2015).

\section{The link between business process management and digital transformation}

As has already been mentioned, digital transformation can be performed by either changing the existing business model with the help of digital technologies or by creating a new, innovative one (Pejić Bach et al., 2018). Hence, if the organization chooses to conduct a digital transformation following the direction of changing the existent business model, it implies changing the existent business processes of the organization. Additionally, the latest study on the state of business process management, conducted on 184 respondents, reveals that the majority of organizations put their focus on incremental changes and the improvement of existing business processes, in combination with adopting new technologies (Harmon, 2018). Although Tapscott (1997) recognizes that the new digital economy can lead to the creation of new business models, he also underlines the possibility of using digital technology tools in order to change and restructure existing business processes.

Consequently and as already pointed out, it seems that parts of digital transformation endeavors can be correlated with business process management in organizations. Heberle, Lowe, Gustafsson, and Vorrei (2017) argue that for successful digital transformation, it is essential to automate existing business processes within an organization by digitization, integration, and analysis of data, as well as the establishment of new business models by digitalization. In accordance, vom Brocke et al. (2017) stress the significant role that structured data along with stable, reliable, and integrated processes play in digital transformation. Moreover, de Bruin (2007) discovered that business process management initiatives are experiencing an evolution from "process improvement to business transformation." Collaboration between digital transformation and business process management can bring new opportunities for business process management, since, according to Rosemann (2014), business process management currently lacks a proactive, opportunity, and innovation-seeking initiative.

Indeed, in the recent period, numerous members of both academia and practice have recognized the importance of business process management for digital transformation. For example, Araujo (2017), Francis (2018), and Sandle (2018), as well as Kirchmer, Franz, and Gusain (2018) view the role of business process management within a digital transformation as a central one. Moreover, Sandle (2018) explains how business process management can help in the process of digital transformation by pointing out five ways, 
being: (i) the use of process engines, (ii) effective use of business analytics, (iii) effective use of content management, (iv) the use of collaboration tools, and (v) using automation to become an agile organization.

Having in mind all previously stated facts, and to the best of authors' knowledge, there is still no clear theoretical framework that combines digital transformation and business process management. Moreover, some authors indicate the need for further investigation of the role of business process management in digital transformation (e.g., Van Looy, 2018). Hence, this paper aims to shed some light on the role that business process management plays in the digital transformation process.

\section{RESEARCH METHODS}

\section{Search strategy for the literature review}

One of the goals of this paper is to review the body of literature on a given topic. In order to accomplish this goal, a literature review was conducted and carried out in October 2018.

During the literature search process, it has been essential to gather relevant papers that would support the chosen topic of this study. For this purpose, the authors have reviewed the literature on the following databases of scientific articles: Web of Science and Scopus. In addition, aiming for more precise research results, as well as a deeper coverage of the body of literature and a better understanding, the AIS Electronic Library has also been included in the search process. Taking into consideration the fact that Information Science is an interdisciplinary field, as well as the fact that there is a wide research spectrum of business process management concepts and digital transformation concepts, no restrictions for research fields have been set during the search process. Therefore, all research fields and indexes that are covered in the chosen scientific papers databases have been included in the search process. Bearing in mind that the relationship between these two concepts has only recently attracted attention from authors within scientific circles, the process of research has not been limited to a certain period of time.

Consequently, all papers written throughout the years have been taken into account in the search process. Figure 1 presents the number of published papers found in all searched databases (Web of Science, Scopus, and AIS Electronic Library). As is visible from Figure 1, it shows that only in the last couple of years has an increased interest been seen within the scientific circles for a topic related to the relationship between business process management and digital transformation concepts. Since conference 
papers are key sources for the literature review process in the Information Science field (Danneels, 2016), proceedings papers, journal articles, and book chapters have been included in this literature review research. No language restrictions have been set in the literature search process.

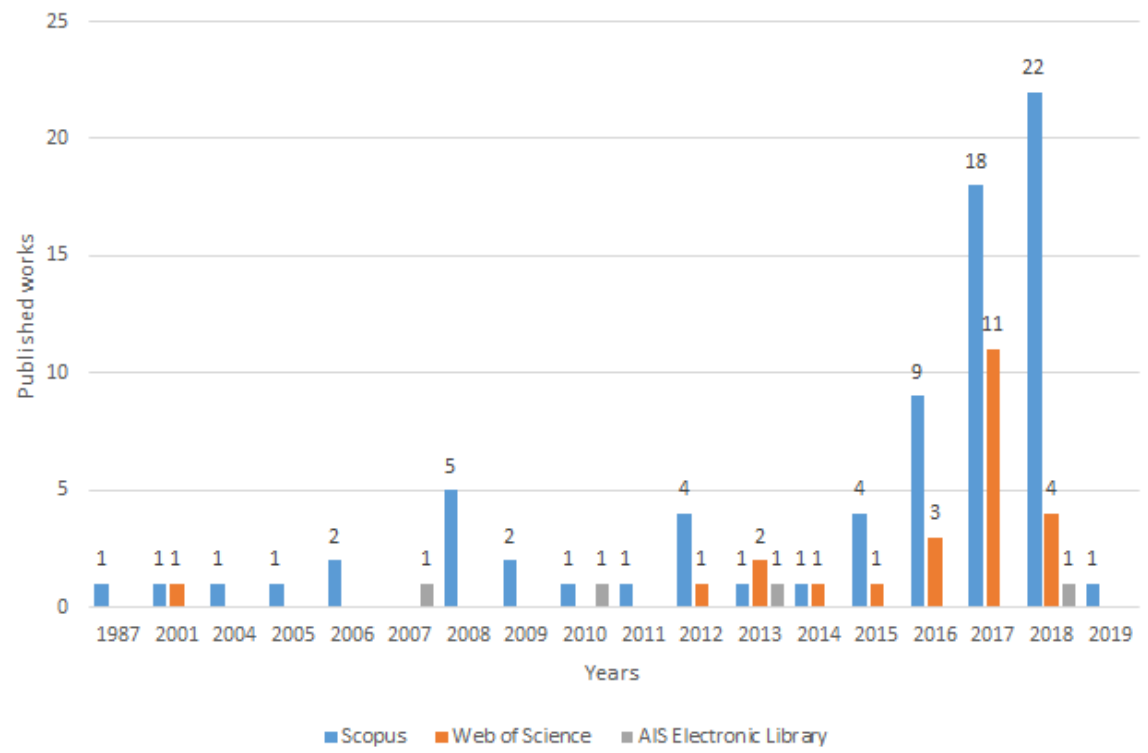

Figure 1. Number of works published in the Web of Science, Scopus and AIS Electronic Library in the period 1987-2019

\section{The selection process of articles for analysis}

The first step in this literature review has been the definition of search keywords. The focus on selecting adequate keywords has been on terms related to the concepts of business process management and digital transformation. Given that the main goal of this literature review is to identify the links between the named two concepts, the combinations of keywords that have been chosen and used in the literature search are presented in Table 1.

Considering that the terms digitization, digitalization, and digital transformation are being used interchangeably, as outlined in more detail in the Digital transformation section, a broad range of keyword combinations have been included in the search. Table 2 presents the results that have been acquired according to the above-mentioned combination of keywords for each database. 
Table 1. Keywords combinations by searched databases

\begin{tabular}{|c|c|}
\hline Database & Keyword combination \\
\hline Web of Science & $\begin{array}{l}\text { TOPIC: (“digital transformation” OR “digital business” OR } \\
\text { "digitization" OR “digitalization”) AND TOPIC: (“business } \\
\text { process* management" OR “business process management } \\
\text { OR “process* management”) }\end{array}$ \\
\hline Scopus & $\begin{array}{l}\text { TITLE-ABS-KEY ("digital transformation" OR "digital business" } \\
\text { OR "digitization" OR "digitalization") AND TITLE-ABS-KEY } \\
\text { ("business process* management" OR "BUSINESS PROCESS } \\
\text { MANAGEMENT" OR “process* management") }\end{array}$ \\
\hline AIS Electronic & subject: ("digital transformation" OR "digital business" OR \\
\hline Library & $\begin{array}{l}\text { "digitization" OR "digitalization") AND subject: (“business } \\
\text { process* management" OR "business process management" } \\
\text { OR "process* management") }\end{array}$ \\
\hline
\end{tabular}

Table 2. Keyword combinations by searched databases

\begin{tabular}{|c|c|c|c|c|c|c|}
\hline Database & Total hits & $\begin{array}{l}\text { Journal } \\
\text { articles }\end{array}$ & $\begin{array}{l}\text { Conference } \\
\text { papers }\end{array}$ & $\begin{array}{l}\text { Other forms of } \\
\text { works }\end{array}$ & $\begin{array}{l}\text { Languages } \\
\text { (number of } \\
\text { papers) }\end{array}$ & $\begin{array}{l}\text { Time } \\
\text { period of } \\
\text { publishing }\end{array}$ \\
\hline Web of Science & 24 & 9 & 15 & 0 & $\begin{array}{l}\text { English (22), } \\
\text { German (2) }\end{array}$ & $2001-2018$ \\
\hline Scopus & 75 & 11 & 53 & $\begin{array}{l}1 \text { article in } \\
\text { press, } \\
1 \text { book, } \\
2 \text { book chapters, } \\
53 \text { conference } \\
\text { papers } \\
7 \text { conference } \\
\text { reviews }\end{array}$ & $\begin{array}{l}\text { English (70), } \\
\text { Chinese (1), } \\
\text { German (3), } \\
\text { Portuguese } \\
\text { (1) }\end{array}$ & 2010-2019 \\
\hline AIS Electronic Library & 4 & 2 & 2 & 0 & English (4) & $2007-2018$ \\
\hline
\end{tabular}

A total of 103 studies have been found using the defined keywords, which could potentially be included in the analysis.

Figure 2 shows the diversity of research areas in which articles and conference proceedings papers have been published within the Web of Science database. The results presented in Figure 2 show that the majority of papers published within the Web of Science database belongs to the area of computer science (11), followed by the area of engineering (8). On the other side, a minority of the articles found, belong to the areas of cardiovascular system and cardiology, ophthalmology, library science and social sciences, and other topics (1 article in each area). 




Figure 2. Number of published papers by research area within the Web of Science database

In the second step of the literature review, the search results have been refined. Papers that had access restrictions have been eliminated first, after which 100 papers remained for further analysis. Alongside the excluded papers with access restrictions, papers that have been found in more than one searched database have also been removed from further analysis, leaving 78 papers in the analysis. Next, due to the language barrier, papers that have not been written in English have also been removed from further analysis. Consequently, 73 papers remained for analysis. Furthermore, within the Scopus database, a total of 8 works have been excluded, 7 conference proceedings and 1 book, due to the fact that they only referred to business process management and digital transformation in their titles or introduction editorial text, and not in the content itself. Accordingly, 65 papers were taken onto the next step of the literature review process.

In the third step of the literature review, all of the papers have been read and analyzed according to their topic. Papers were considered relevant if they referred to the phenomenon of business process management and digital transformation. In each paper, the accuracy of the search keywords, as well as the topic matching of each article with the chosen topic of the research, was sought. For instance, the abbreviation BPM has been used in several articles for the expression "Beam Position Monitor," which is not 
in accordance with the use of BPM as "Business Process Management." Therefore, those papers were excluded from the analysis in this step. Papers that have also been excluded in the further analysis were dealing with the topic of business process management or digital transformation focusing on the philosophical standpoint of programming, boundary management, or describing new business modeling frameworks. Consequently, in the remaining 40 papers, including journal articles, proceedings papers, and book chapters, an analysis of linkages between business process management and digital transformation has been made.

\section{Content analysis model}

Since diverse definitions of the digital transformation concept exist, this study opted for the holistic view on digital transformation represented in the works of Valdez-de-Leon (2016) and MIT Sloan researchers (e.g., Kane, Palmer, Philips, Kiron, \& Buckley, 2015; 2016). For the purpose of this study, digital transformation is viewed as a phenomenon affecting all areas of an organization, induced by, but not limited to, technological changes. Moreover, business process management is observed through the lens of digital transformation in order to shed some light on the intersections and opportunities that business process management is facing in the digital transformation era.

Based on the preliminary literature review, a conceptual framework used for paper analysis has been constructed in order to systematically identify the intersections of digital transformation and business process management. A presented framework is following the works of Valdez-deLeon (2016), Sebastian et al. (2017), and Reis et al. (2018). According to Reis et al. (2018), digital transformation comprehension can be classified into three main views: (i) technological, (ii) organizational, and (iii) social. The technological view adopts new digital technologies implementation; the organizational view focuses on business process changes, new business model introductions and consequently other management related practices; while the social view considers social factors, including the impact of digital transformation on customers (Reis et al., 2018). Sebastian et al. (2017) define three essential components for successful digital transformation: (i) a digital strategy, (ii) an operational backbone, and (iii) a digital services platform. The last two components are related to technology and are considered as capabilities for the successful implementation of digital goals set up in the strategy (Sebastian et al., 2017). Consequently, a strategic view has been added to the framework of this research. 
On the other hand, Valdez-de-Leon (2016) finds thatorganizations address, besides strategy and technology, several other components in the process of digital transformation that form the following dimensions: (i) organization, (ii) customer, (iii) ecosystem, (iv) operations and (v) innovation. For the purpose of this review, the identified components of digital transformation in the literature overview have been merged in agreement with the holistic definition of digital transformation. This article is following, reorganized and adapted to match the research context of digital transformation and business process management intersections. Hence, a framework is organized into four main dimensions representing four views on digital transformation: (i) strategic alignment (strategic view), (ii) goals (organizational view), (iii) business process management and digital transformation orchestration (technological view), and (iv) roles (social view). Some dimensions have been divided into sub-dimensions, which are more closely connected to the business process domain, as presented in Figure 3.

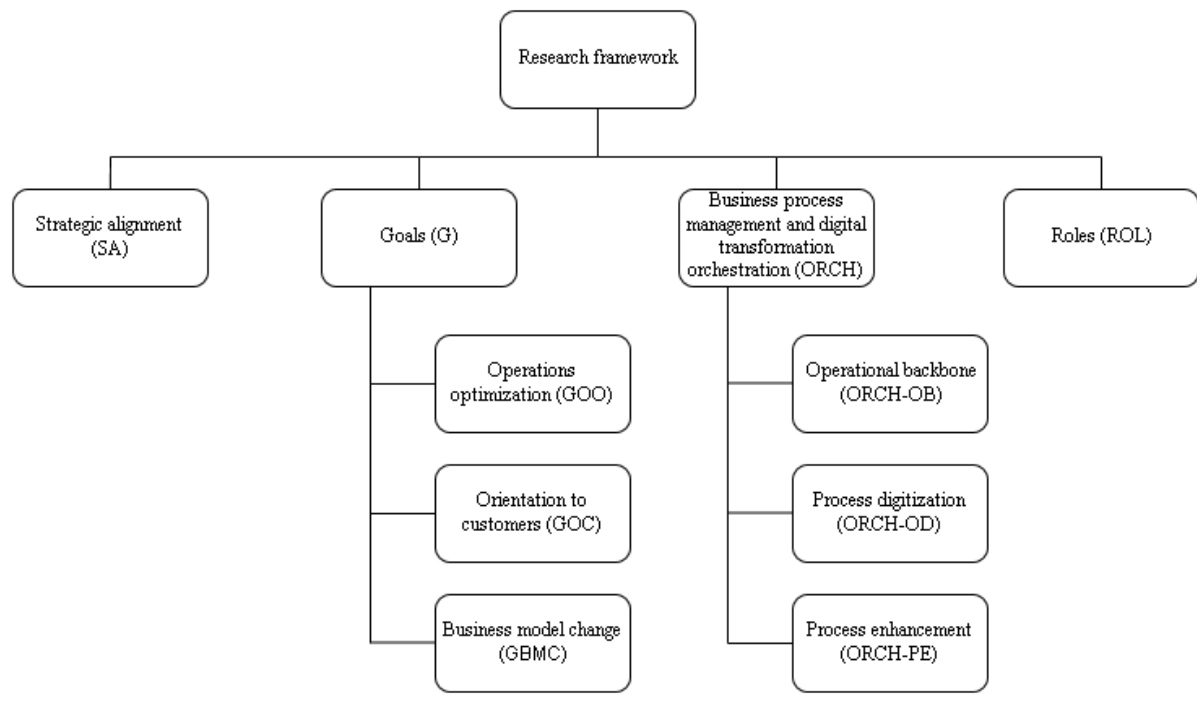

Figure 3. Theoretical framework for investigating intersections of business process management and digital transformation

The strategic alignment (strategic view) dimension comprises organizations' attitudes towards digital transformation and is a basis for conducting all other activities and changes in the process of digitally transforming the organization. Organizations that have a clear digital vision and a will to pursue the advantages that a transformation can bring will 
actively encourage digital initiatives and devote financial investments to the development of digital projects (Matt et al., 2015; Valdez-de-Leon, 2016). To accomplish this level, an enactment of digital strategy is inevitable. In order to keep up with recent changes in the environment, but also in the organization, digital strategy is constantly evolving and being revised until at some point, reach the status where it is an organizational decision driver (Chanias \& Hess, 2016; Valdez-de-Leon, 2016). Nevertheless, as noticed by Andriole (2017), not every organization needs to conduct a (radical) digital transformation. In their study investigation, Hess, Matt, Benlian, and Wiesböck (2016) found that organizational strategies differ in focus and scope. According to Sebastian et al. (2017), there are two main directions that one digital strategy can embrace: (i) focus on customers, and (ii) focus on digitized solutions. In both directions, business processes are likely to be altered in terms of optimization to adapt to customers' need, or they are completely digitized using new and innovative solutions. Therefore, it is possible that the processes and systems behind them are working efficiently and that there is no need to change them (Andriole, 2017), i.e. an alignment with the state of process architecture needs to be considered. Hence, a digital strategy is a "business strategy that incorporates the opportunities that the digital economy presents" (Sebastian et al., 2017, p. 198) and being such, it focuses on the "transformation of products, processes and organizational aspects owing to new technologies" (Matt et al., 2015, p. 339).

The goals dimension (organizational view) gathers activities and initiatives under digital transformation, which can be classified into three subdimensions according to their outcome. Those are (i) operations optimization, (ii) orientation to customers, and (iii) business model change. Some digital transformation initiatives strive to achieve greater efficiency of operations by using technologies and methods elaborated in the technological view concept (Valdez-de-Leon, 2016; Chen, Li, Wu, \& Luo, 2017). Operations optimization can be joined with the means for reaching higher customer satisfaction and inclusion, often through the notions of customer experience, customer engagement, or designing a customer journey (Westerman, Calméjane, Bonnet, Ferraris, \& McAfee, 2011; Sebastian et al., 2017). Informed decisions about new digital solutions and services are brought about based on customer needs (Valdez-de-Leon, 2016). In their study, Piccinini, Gregory, and Kolbe (2015, p. 1645) conclude that digital transformation customers have "a more active role in co-production, co-creation, and problemsolving". Strong orientation to customers is also at the center of the business process management related concept of process orientation (Kohlbacher \& Gruenwald, 2011). On the other hand, if digital transformation results in a change to a business model, it is a more radical change in organizations' 
processes and value-chain that "generates a new revenue stream" (Schallmo, Williams, \& Boardman, 2017). Some of the companies will be enforced to change their business models completely due to digital disruption in their industry. However, some can take more time and adapt through incremental changes in customer-related processes and operations (Westerman, Tannou, Bonnet, Ferraris, \& McAfee, 2012).

The business process management and digital transformation orchestration dimension encompasses a technological view on digital transformation and is divided into three sub-dimensions: (i) process digitization, (ii) operational backbone, and (iii) process enhancement. Reis et al. (2018) suggested that when considering the technological aspect, new digital technologies are the root of digital transformation. So-called "primary" and "secondary" digital technologies (Spremić, 2017b, p. 215) or "SMACIT" technologies (Sebastian et al., 2017, p. 197) are utilized in organizations, including social, mobile, cloud, Internet of Things, big data technology and related methods, robotics and other. Although not every organization can digitize its products, every industry has the possibility to digitize its processes for raising the quality of services or gaining real-time decision-making data (Kohli \& Johnson, 2011). Digital technologies are hence implemented for process digitization, integrated through a digital services platform, and provide agility and flexibility (Valdez-de-Leon, 2016; Sebastian et al., 2017).

Nevertheless, achieving this flexibility and speed can be daunting, since existing IT systems and business process models are often inoperable with new digital solutions or do not provide the required information (Andriole, 2017; Erjavec et al., 2018). Therefore, in order to be able to provide an adequate information flow and reliability for digitization changes, an efficient operational system in the background is required. This operational backbone includes technologies well known in information systems literature such as integral Enterprise Resource Planning systems, customer relationship management systems or business process modeling and simulation software (Andriole, 2017; Sebastian et al., 2017). Although, according to Reis et al. (2018), process change is a part of the organizational view, this paper categorized process enhancement into the technological view following the other two base-works (Sebastian et al., 2017; Valdez-de-Leon, 2016). The activities of business process management are placed under the technology dimension of Valdez-de-Leon (2016). In more detail, an alignment of the processes with digital IT architecture and the optimization of end-to-end processes are considered (Valdez-de-Leon, 2016, p. 30). Sebastian et al. (2017) point out that alongside systems integration, standardization of processes is taking place. Hence, in order to make a clear distinction between the process changes occurring in the first two sub-concepts, respectively 
process digitization and operational backbone, a process enhancement subdimension is introduced in this view. Process enhancement indicates that process changes don't necessarily need to be driven by technology, but can be small and innovative process improvements using other available resources, as also noticed by Kane et al. (2016).

The roles dimension (social view) refers to new, digital roles being introduced in organizations and their interoperability with existing positions. In most literature, higher managing roles are investigated, i.e. CxOs alongside the introduction of the CDO (Chief Digital Officer) role (Matt et al., 2015; Singh \& Hess, 2017). Similar to the prior research on business-IT alignment, where the impact and importance of the $\mathrm{CIO}$ (Chief Information Officer) role and other IT executives was stressed (Queiroz, 2017), the CIO-CEO (Chief Executive Officer) relationship is still discussed, but now in the context of digital transformation (Westerman et al., 2012). Although ClOs can still be found having a subordinate position, for instance in relation to the $\mathrm{COO}$ (Chief Operating Officer), digital transformation teams are comprised of IT, process and other business sector employees (Erjavec et al., 2018) owing to the "crossfunctional characteristics" of digital transformation (Matt et al., 2015).

\section{RESULTS ANALYSIS AND DISCUSSION}

Within this section, the results obtained from the conducted analysis of the selected 40 papers gained through the process of the literature search are presented and discussed.

For the purposes of this paper, and the conduction of the literature review, the authors rely on a content analysis model, established through the previous research by Valdez-de-Leon (2016), Sebastian et al. (2017) and Reis et al. (2018). The model is made up of four dimensions that represent a potential link between the two concepts, business process management, and digital transformation. As previously explained, the first dimension is related to the strategic importance of business process management in digital transformation and vice versa, while the second dimension of the model considers the goals that are to be achieved in the observed company, simultaneously observing them through the sub-dimensions of business operations optimization, business orientation to customers or business model change. The third dimension of the content analysis model refers to the orchestration of business process management and digital transformation concepts, relying on the following three sub-dimensions: operational backbone, process digitization, and process enhancement. The last, fourth dimension refers to organizational roles that connect the concepts 
of business process management and digital transformation in a particular business segment. Therefore, all 40 papers have been analyzed according to the four categories of the selected content analysis model, and the results of the analysis are shown in Table 3.

As mentioned before, the interest of researchers in the relationship between business process management and digital transformation concepts has been growing in recent years. Therefore, for the purpose of this paper, it has been decided to examine the parts of the content analysis model through the publishing years of the analyzed papers and to show which connecting dimensions, between the business process management and digital transformation concepts, have been in the focus of researchers for each year. The results are shown in Figure 4.

As is notable from Figure 4, initially the interest in linking business process management and digital transformation has been more focused on the observation and analysis of the potential linkage among organizational goals, process digitization or creating new products, and providing new services. It is evident from Figure 4 that in 2009 the interest of researchers in the area of linking the business process management and digital transformation concepts was mostly focused on the goals of changing the business model, while the biggest focus in 2012 was directed on process digitization within business process management and digital transformation orchestration. In 2013, articles were equally focused on the links between the business process management concept and digital transformation concept in terms of improving the process within the organization and their digitization. In 2015 , a leading place of interest took on the dimension of the organizational roles which appear within the organization as a result of a collaboration between digital transformation and business process management. It is evident that the biggest number of papers that are related to the topic of the relationship between business process management and digital transformation, in the context of all categories within the chosen model, have been published in the last two years. The three most often contained categories of the content analysis model within the analyzed papers are: (i) business process management and digital transformation orchestration - process enhancement, (ii) business process management and digital transformation orchestration - process digitization, and (iii) roles in business process management and digital transformation collaboration. 


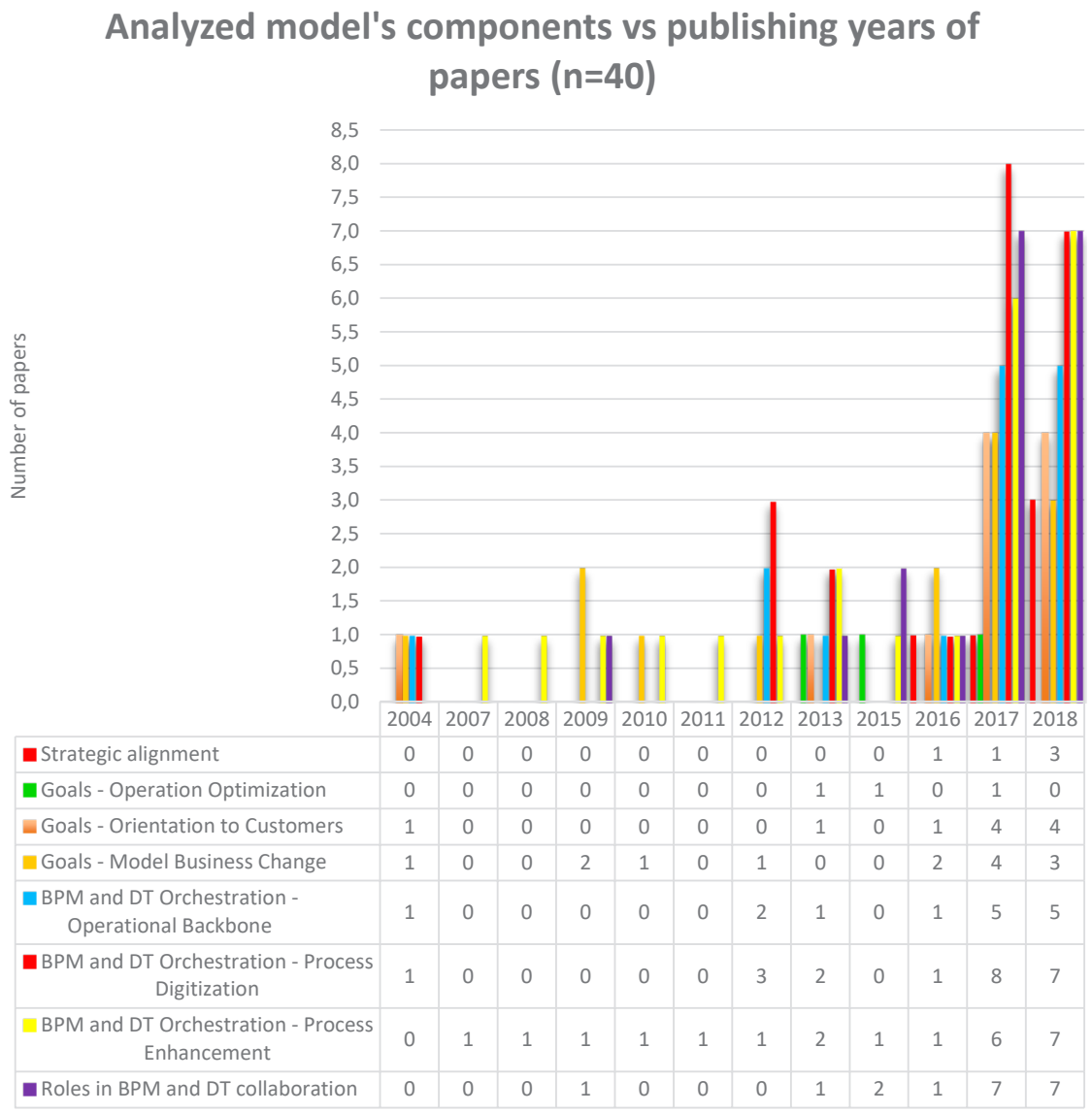

Figure 4. Frequency of appearance of the components of the model within the analyzed articles by publication year

Each paper has been read in detail, observed and, according to the content, assigned to one or more dimensions based on the content analysis model. Consequently, Table 3 has been prepared, showing the dimensions of content analysis model and the papers assigned to each dimension according to its content. Table 3 contains all papers listed by the authors of the paper. In addition, each component of chosen content analysis model has been coded, as shown in Figure 3. 
Table 3. Matrix of analyzed papers (in alphabetical order)

\begin{tabular}{|c|c|c|c|c|c|c|c|c|}
\hline Paper & SA & GOO & GOC & GBMC & $\begin{array}{l}\mathrm{ORCH}- \\
\mathrm{OB}\end{array}$ & $\begin{array}{l}\text { ORCH- } \\
\text { PD }\end{array}$ & $\begin{array}{l}\text { ORCH- } \\
\mathrm{PE}\end{array}$ & $\begin{array}{l}\text { ROL- } \\
\text { BPMDT }\end{array}$ \\
\hline $\begin{array}{l}\text { Cocca, Marciano, Rossi, and } \\
\text { Alberti (2018) }\end{array}$ & & + & + & & + & + & + & + \\
\hline $\begin{array}{l}\text { Dallasega, Rauch, and Frosolini } \\
\text { (2018) }\end{array}$ & & + & & & & & + & + \\
\hline $\begin{array}{l}\text { Denner, Puschel, and Roglinger } \\
\text { (2018) }\end{array}$ & & & & & & & & + \\
\hline Faria and Nóvoa (2017) & & & & & & + & + & \\
\hline $\begin{array}{l}\text { Feibert, Hansen, and Jacobsen } \\
\text { (2018) }\end{array}$ & & + & + & & + & & + & \\
\hline Fleig and Maedche (2017) & & & & & & & + & + \\
\hline Flores, Vera, and Tucci (2009) & & & & + & & & & + \\
\hline Glykas (2004) & & & + & + & + & + & & \\
\hline Grabis and Kampars (2018) & & & & & + & + & + & \\
\hline $\begin{array}{l}\text { Heberle, Löwe, Gustafsson, } \\
\text { and Vorrei (2017) }\end{array}$ & & + & + & + & + & + & + & \\
\hline $\begin{array}{l}\text { Heliades, Halkiopoulos, and } \\
\text { Arvanitis (2017) }\end{array}$ & & & & & & + & & \\
\hline Herzberg and Kunze (2015) & & + & & & & & + & + \\
\hline $\begin{array}{l}\text { Hildebrandt, Debois, Slaats, } \\
\text { and Marquard (2017) }\end{array}$ & & & & & & + & & \\
\hline $\begin{array}{l}\text { Imgrund, Fischer, Janiesch, and } \\
\text { Winkelmann (2018) }\end{array}$ & & & & & + & + & & + \\
\hline Joubert, and Roodt (2010) & & & & + & & & + & \\
\hline $\begin{array}{l}\text { Karla, Friedrichsn, and Braun } \\
\text { (2011) }\end{array}$ & & & & & & & + & \\
\hline Kirchmer (2015) & & & & & & & & + \\
\hline $\begin{array}{l}\text { Kirchmer, Franz, and Gusain } \\
\text { (2018) }\end{array}$ & + & & & & & + & + & + \\
\hline $\begin{array}{l}\text { Kirkham, Wood, Winfield, } \\
\text { Coolin, and Smallwood (2009) }\end{array}$ & & & & + & & & + & \\
\hline $\begin{array}{l}\text { Komarov, Konovalov, and } \\
\text { Kazantsev (2016) }\end{array}$ & & & & + & & & & \\
\hline $\begin{array}{l}\text { Lederer, Betz, and Schmidt } \\
\text { (2018) }\end{array}$ & + & + & & + & + & + & + & + \\
\hline $\begin{array}{l}\text { Lederer, Betz, Kurz and, } \\
\text { Schmidt (2017) }\end{array}$ & & & & + & + & + & & + \\
\hline $\begin{array}{l}\text { Lederer, Knapp, and Schott } \\
\text { (2017) }\end{array}$ & & & + & & + & + & + & + \\
\hline Leyh, Bley, and Seek (2017) & + & & & & & & & + \\
\hline Manferdini (2012) & & & & & & + & & \\
\hline Manfreda (2017) & & & + & + & + & + & & + \\
\hline $\begin{array}{l}\text { Mathrani, Mathrani, and } \\
\text { Viehland (2013) }\end{array}$ & & + & + & & + & + & + & + \\
\hline
\end{tabular}




\begin{tabular}{|c|c|c|c|c|c|c|c|c|}
\hline Paper & SA & GOO & GOC & GBMC & $\begin{array}{l}\text { ORCH- } \\
\text { OB }\end{array}$ & $\begin{array}{l}\text { ORCH- } \\
\text { PD }\end{array}$ & $\begin{array}{l}\text { ORCH- } \\
\text { PE }\end{array}$ & $\begin{array}{l}\text { ROL- } \\
\text { BPMDT }\end{array}$ \\
\hline Neubauer and Krenn (2017) & & & & & + & + & & \\
\hline $\begin{array}{l}\text { Oberhauser, Pogolski, and } \\
\text { Matic (2018) }\end{array}$ & & & & & & + & & \\
\hline $\begin{array}{l}\text { Paschek, Luminosu, and } \\
\text { Draghici (2017) }\end{array}$ & & & & & & & + & + \\
\hline Rohner (2013) & & & & & & + & + & \\
\hline Roszkowska (2017) & & & & + & & & + & \\
\hline $\begin{array}{l}\text { Seidel, Adams, ter Hofstede, } \\
\text { and Rosemann (2007) }\end{array}$ & & & & & & & + & \\
\hline $\begin{array}{l}\text { Sienou, Lamine, Karduck, and } \\
\text { Pingaud (2008) }\end{array}$ & & & & & & & + & \\
\hline Sun, Chang, and Wan (2012) & & & & & + & + & + & \\
\hline Van Looy (2017) & & & + & & & & & + \\
\hline Van Looy (2018) & + & & + & & & & & + \\
\hline Vom Brocke et al. (2016) & + & & + & + & + & + & + & + \\
\hline Wang and Zhang (2012) & & & & + & + & + & & \\
\hline $\begin{array}{l}\text { Warnecke, Gevorkjan, and } \\
\text { Teuteberg (2018) }\end{array}$ & & & & & & + & + & \\
\hline
\end{tabular}

As can be seen from Table 3, when it comes to strategic alignment between business process management and digital transformation concepts, a total of 5 papers deals with business process management strategic implications within digital transformation and vice versa. For example, Kirchmer et al. (2018) argue that business process management is a source of significant value for organizations, in terms of transforming strategy into execution based on people and technology, and therefore plays a central role in the process of digital transformation by enabling digitalization and constant strategy execution. On the other hand, Van Looy (2018) indicates that service delivery to customers and stakeholders, operational excellence, and expansion are the shared strategic reasons between business process management and digital transformation.

In the case of highlighting organizational goals as a linkage between the business process management and the digital transformation concepts, out of 40 selected works, 20 of them are relying on one or more of the three subdimensions that fall under the dimension of goals. Out of those 20 papers, in 7 of them, business optimization goal is mentioned. Furthermore, in 10 works, authors mention business orientation towards customers as a goal, while most of the papers ( 12 of them) mention the goal of business model change as the link between the business process management and the digital transformation concepts. Based on the obtained results, it is interesting to 
notice that the most common combination of business goals, contained in the selected papers, is the combination of business orientation towards customers and changes in the business model. Cocca et al. (2018) conducted research in a manufacturing company striving to become a "smart factory." According to them, the transformation was provoked by the high volatility of external business factors in the environment, as well as the change in customers' expectations (Cocca et al., 2018). Customers are becoming more demanding in their requirements, as also noticed by Feibert et al. (2017), expecting highquality and tailor-made services, even if core business is product-based (Cocca et al., 2018; Glykas, 2004). At the same time, they strongly anticipate those new digital services offering to be free of charge (vom Brocke et al., 2016). In such a customer-oriented atmosphere, operations optimization through the analysis of supply chain management can establish end-to-end business process integration in order to create added-value for customers (Feibert et al., 2017), which is consistent with (re)designing customers' journeys.

Regarding innovation potential, Van Looy (2017) investigated the BPM and digital innovation relationship in organizations and found them to be complementary, however, the direction of the influence is still not clear. Innovations and improvements in the performance of operations are often linked with an external knowledge source. Digital enterprises reach out to the academic community to solicit ideas and gain professional knowledge on implementation and evaluation methods (vom Brocke et al., 2016). Moreover, according to Roszkowska (2017, p. 53), "most organizations need digital transformation to effectively access external knowledge." When it comes to more significant changes in influencing business models, some companies are radically changing their ways of work by deploying numerous information and communication technologies. An example of this kind is the disruptive pressures in the publishing and printing industry (Glykas, 2004). Discussion on the level and source of innovations, and resultant changes, can be stressed in relation to incentives for an ambidextrous organization and exploitative and explorative BPM capabilities (van Looy, 2017; 2018; Roszkowska, 2017). Besides the more momentous change to the underlying business model intertwined with the incremental optimization of business processes that ambidexterity is offering, a third concept regarding the organizational business model is noticeable. Use of technologies and exploitation of data that is now being both collected and analyzed enables the existence and creation of various business models within one organization, specifically arranged for different users (Kirkham et al., 2009). Kirchmer (2013, p. 131) notices that "static business models are no longer able to keep pace with such dynamic change." Lederer et al. $(2017$, p. 4) refer to this phenomenon as "case-driven BPM," which is in line with other authors 
arguing that business processes are becoming more dynamic and require flexibility (Heikkinen \& Hilgarth, 2016).

The orchestration of business process management and digital transformation concepts, in one or more of its dimensions, is contained within 34 of the 40 selected and analyzed papers. When talking about the orchestration of business process management and digital transformation concepts in terms of "Operational Backbone" and, therefore, about the application of standard systems such as Enterprise Resource Planning systems or generally so-called core IT in business, according to the results, it is noticeable that 15 papers in some way touched upon this kind of linkage between these two concepts. Information and communications technology have great importance as a backbone in the process of digitalization (Feibert et al., 2017). According to Cocca et al. (2018), an Enterprise Information Planning system is considered as the backbone of digital transformation and a key trigger in supporting the implementation processes of this concept within an organization. In the case of shipping companies within the maritime transport industry, information and communications technology as an operating platform brings many business advantages, such as supporting supply chain management, increasing the quality and efficiency of services provided to customers, lessening business costs, etc. (Feibert et al., 2017). According to Kirchmer et al. (2018), various digital technologies and tools greatly support the digitalization of processes within organizations. Therefore, process digitization, as the second dimension of a goal dimension, as it has been defined within the model, has been observed through the use of two different digital technologies in business. According to Spremić (2017b), primary digital technologies include the appliance of mobile technologies, social networks, cloud computing, big data, sensors, and the Internet of Things. The use of primary digital technologies such as cloudbased services opens the path for a possible change from existing internal processes into a connected intelligent business process sequence, which creates new values in the digital transformation environment (Lederer et al., 2017). The application of secondary digital technologies is oriented towards technologies such as additive manufacturing (3D printers), drones, wearable technologies, holograms, virtual and augmented reality, cognitive technologies (artificial intelligence), deep learning algorithms, facial and speech recognition, etc. (Spremić, 2017b). When observing the digitalization process within the management of processes in the organization, digital tools such as processes automation supported by robot technology, process modeling tools, data mining tools, technologies that are appropriate for analytical processes, etc. are being emphasized (Kirchmer et al., 2018). Also, digital technologies such as drones, robotics, mobile technology, Internet of 
Things devices, wearables, virtual and augmented reality, etc., contribute to business processes digitalization and, consequently, to the quality of business performance within the organization (Heberle et al., 2017). According to the results, a total of 22 papers contained one of the technologies mentioned above that supported digitization of the process in a particular business segment. The dimension within the model's component pertaining to the orchestration of business process management and digital transformation concepts and which concerned process improvement was mentioned in a total of 23 articles out of the total number of analyzed articles. According to research results conducted by Mathrani et al. (2017) within three different companies, the process enhancement that was supported by the application of digital technology and digital business strategy was visible through reduced number of errors in the process of price structuring, improved manufacturing, and supply processes, increased organizational competitiveness, automated marketing processes, improvement of production planning and delivery services, better customer service, etc.

When discussing the organizational roles that emerge from the collaboration between business process management and digital transformation concepts, it can be seen from the results that 19 articles recognized the importance of this dimension by mentioning one of the organizational roles through managing the digital transformation process in the organization, participation in the digital transformation of business processes or in another collaborative form that links digital transformation and business process management. Such a high number of papers dealing with this topic confirms its importance. According to many authors, the organizational roles involved in the collaboration between digital transformation and business process management can appear as process owner program manager, participation of internal and external stakeholders, participation of customers, project manager, $\mathrm{ClO}$, Chief Technology Officers (CTO), CEO, CDO, IT process managers, etc. (e.g., Van Looy, 2018, Imgrund et al., 2018, Dallasega et al., 2018, Paschek et al., 2018)

\section{CONCLUSION}

This study presents the results of the literature review on the link between digital transformation and business process management. First, the strategy for the literature search was set. Then, the literature search was conducted, performing searches within the Web of Science, Scopus, and AIS Electronic Library databases, resulting in overall 40 different papers that have been further analyzed in this paper. Next, following the works of Valdez-de-Leon 
(2016), Sebastian et al. (2017), and Reis et al. (2018), a theoretical framework has been developed. The presented framework consists of four dimensions and several sub-dimensions, as explained previously in the paper, which has served as a basis for the content analysis of the results gained by the literature search.

The results of the content analysis indicate that only a small number of authors understand the importance of strategic alignment, which is an indicator that further research is needed in order to deepen the understanding of the topic. Moreover, according to the results, the dimension of business process management and digital transformation orchestration, which consist of three sub-dimensions: operational backbone, process digitization, and process enhancement; occupied the greatest interest of authors in the analyzed papers. In addition, improving processes within the organization was the most common sub-dimension linking the concepts of digital transformation and business process management.

The results regarding digital transformation efforts and goals indicate a greater orientation to customers, who demand a high quality of offered services, tailored according to their needs, even in the case of the primary physical industries. These outcomes can be achieved by rethinking endto-end customer processes through supply chain management. Hence, organizations employ diverse technologies and optimize their operations taking into consideration specifics and requirements of a business. Consequently, digital transformation does not need to drastically change ways of work to the extent that it involves changes in the underlying business model. Nevertheless, the need for greater process flexibility, induced by a customer-centric business and the dynamics of the environment, leads to the novelty of occurrence of multiple business models in one organization. This is consistent with the possibilities that an ambidextrous organizational design is offering. Moreover, a dynamic business model setup where the models' architecture is adapted to suit goals of a certain consumer can be correlated with case-driven BPM, which imposes new opportunities for business process management development and research investigation. Finally, the results regarding the role dimension of the model indicate the importance of understanding the organizational roles in the collaboration between business process management and digital transformation.

In the end, the research framework or content analysis model that has been presented in this paper, which is based on the literature overview and supported by the analyzed literature review papers, is proposed as a theoretical framework for further investigation on business process management in the digital era, especially in relation to digital transformation initiatives and projects in organizations. 
Although this study extends the body of knowledge, there are certain limitations that need to be recognized. One of the limitations refers to the limited access to databases and papers which the researchers had during this study. Another one is the language barrier because of which some of the hits from the literature search had to be dismissed. As for future research plans, one of the possible directions for future research could be to expand the literature search to other databases, besides the three searched for the purpose of this paper.

\section{Acknowledgments}

This research has been partly supported by University of Zagreb under the project Digital Transformation of Croatian Companies and partly by Croatian Science Foundation under the project PROSPER - Process and Business Intelligence for Business Performance (IP-2014-09-3729).

\section{References}

Akos, D. M., \& Tsui, J. B. (1996). Design and implementation of a direct digitization GPS receiver front end. IEEE Transactions on Microwave Theory and Techniques, 44(12), 2334-2339. https://doi.org/10.1109/22.554550

Alotaibi, Y. (2016). Business process modelling challenges and solutions: A literature review. Journal of Intelligent Manufacturing, 27(4), 701-723. https://doi.org/10.1007/s10845-014-0917-4

Andriole,S.J. (2017). Five myths about digitaltransformation. MITSloanManagement Review, 58(3), 20-22. Retrieved from http://mitsmr.com/2ki2h8A

Araujo, C. (2017, March). Why BPM is now taking a central role in digital transformation. CIO. Retrieved 15 November, 2018, from https://www. cio.com/article/3176077/software/why-bpm-is-now-taking-a-centralrole-in-digital-transformation.html

Bosilj Vukšić, V., Ivančić, L., \& Suša Vugec, D. (2018). A preliminary literature review of digital transformation case studies. In ICMIT 2018: 20th International Conference on Managing Information Technology (pp. 737-742). Retrieved from https://waset.org/Publication/a-preliminaryliterature-review-of-digital-transformation-case-studies-/10009516

Bosilj Vukšić, V., Suša Vugec, D., \& Lovrić, A. (2017). Social business process management: Croatian IT company case study. Business Systems Research Journal, 8(1), 60-70. https://doi.org/10.1515/bsrj-2017-0006

Buh, B. (2016). Approaches towards business process management adoption under different organizational cultures (Doctoral dissertation). Ljubljana: University of Ljubljana, Faculty of Economics.

Chanias, S., \& Hess, T. (2016). Understanding digital transformation strategy formation :InsightsfromEurope'sautomotiveindustry. PACIS2016Proceedings, Paper 296. Retrieved from https://www.researchgate.net/profile/Thomas_ 
Hess6/publication/311443349_Understanding_Digital_Transformation Strategy_Formation_Insights_from_Europe's_Automotive_Industry/ links/5c310fe2458515a4c7109a03/Understanding-Digital-TransformationStrategy-Formation-Insights-from-Europes-Automotive-Industry.pdf

Chen, Z., Li, Y., Wu, Y., \& Luo, J. (2017). The transition from traditional banking to mobile internet finance: An organizational innovation perspective a comparative study of Citibank and ICBC. Financial Innovation, 3(12). https://doi.org/10.1186/s40854-017-0062-0

Cocca, P., Marciano, F., Rossi, D., \& Alberti, M. (2018). Business software offer for industry 4.0: The SAP case. IFAC-PapersOnLine, 51(11), 1200-1205. https://doi.org/10.1016/j.ifacol.2018.08.427

Dallasega, P., Rauch, E., \& Frosolini, M. (2018). A lean approach for real-time planning and monitoring in engineer-to-order construction projects. Buildings, 8(3), 38. https://doi.org/10.3390/buildings8030038

Danneels, L. (2016). Digital business innovation of public services. In Electronic Government and Electronic Participation: Joint Proceedings of Ongoing Research, Ph.D. Papers, Posters and Workshops of IFIP EGOV and EPart 2016 (Vol. 23, p. 320). IOS press

de Bruin, T. (2007). Insights into the Evolution of BPM in Organisations. ACIS 2007 Proceedings: 18th Australasian Conference on Information Systems (pp. 632-642). Retrieved from https://doi.org/10.1073/pnas.0400014101

Denner, M-S., Puschel, L.C., \& Roglinger, M. (2018). How to exploit the digitalization potential of business processes. Bus Inf Syst Eng, 60(4), 331-349. https://doi.org/10.1007/s12599-017-0509-x

DeToro, I., \& McCabe, T. (1997). How to stay flexible and elude fads. Quality Progress, 30(3), 55-60.

Erjavec, J., Manfreda, A., Jaklič, J., Fehér, P., Indihar Štemberger, M., Szabó, Z., \& Kö, A. (2018). Case studies of successful digital transformation in Slovenia And Hungary. In 5th International Conference on Management and Organization. Ljubljana, Slovenia.

Faria, J. A., \& Nóvoa, H. (2017). Digital transformation at the University of Porto. In International Conference on Exploring Services Science (pp. 295308). Springer, Cham. https://doi.org/10.1007/978-3-319-56925-3_24

Feibert, D. C., Hansen, M. S., \& Jacobsen, P. (2017). An integrated process and digitalization perspective on the shipping supply chain-A literature review. In Industrial Engineering and Engineering Management (IEEM), 2017 IEEE International Conference on Industrial Engineering and Engineering Management (IEEM) (pp. 1352-1356). IEEE. https://doi. org/10.1109/IEEM.2017.8290113

Fleig, C. (2017). Towards the design of a process mining-enabled decision support system for business process transformation. In X. Franch, J. Ralyte, R. Matulevicius, C. Salinesi and R. Wieringa (Eds.), CAiSE 2017 Forum and Doctoral Consortium Papers (pp. 170-178). Retrieved from https://pdfs. semanticscholar.org/8b2e/dedd8c1c5c129b018fceeb7ec1b193377bd0.pdf 
Flores, M., Vera, T., \& Tucci, C. (2009). Discovering collaboration and knowledge management practices for the future digital factory. In Working Conference on Virtual Enterprises (pp. 623-632). Springer, Berlin, Heidelberg. https://doi.org/10.1007/978-3-642-04568-4_64

Francis, J. (2018, June). How BPM is Taking a Central Role in Digital Transformation. Retrieved 15 November, 2018, from https://kissflow. $\mathrm{com} / \mathrm{bpm} / \mathrm{how}$-bpm-is-taking-a-central-role-in-digital-transformation/

Gartner Inc. (2018a). Gartner IT Glossary - Digitization. Retrieved 15 November, 2018, from https://www.gartner.com/it-glossary/digitization Gartner Inc. (2018b). Gartner IT Glossary - Digitalization. Retrieved 15 November, 2018, from https://www.gartner.com/it-glossary/digitalization Glykas, M. (2004). Workflow and process management in printing and publishing firms. International Journal of Information Management, 24(6), 523-538. https://doi.org/10.1016/j.ijinfomgt.2004.08.003

Grabis, J., \& Kampars, J. (2018). Application of microservices for digital transformationofdata-intensivebusinessprocesses.In/CEIS(2)(pp.736-742). Retrieved from https://www.scitepress.org/papers/2018/68052/68052. pdf https://doi.org/10.5220/0006805207360742

Grau, C., \& Moormann, J. (2014). Investigating the relationship between process management and organizational culture: Literature review and research agenda. Management and Organizational Studies, 1(2), 1-17. https://doi.org/10.5430/mos.v1n2p1

Hammer, M. (2015). What is business process management? In J. vom Brocke \& M Rosemann (Eds.), Handbook on Business Process Management 1: Introduction, Methods, and Information Systems, 2nd edition (pp. 3-16). Berlin Heidelberg: Springer. http://dx.doi.org/10.1007/978-3-642-45100-3_1 Harmon, P. (2018). The State of Business Process Management 2018. BPTrends. Retrieved from https://www.bptrends.com/2018-state-ofbusiness-process-management-Ip/

Harmon, P. (2007). Business Process Change: a Guide for Business Managers and BPM and Six Sigma Professionals. Waltham: Morgan Kaufmann Publishers. Harmon, P. (2003). Business Process Change: A Manager's Guide to Improving, Redesigning, and Automating Processes. Amsterdam; Boston: Morgan Kaufmann.

Heberle, A., Lowe, W., Gustafsson, A., \& Vorrei, O. (2017). Digitalization canvas - Towards identifying digitalization use cases and projects. Journal of Universal Computer Science, 23(11), 1070-1097. https://doi. org/10.3217/jucs-023-11-1070

Heliades, G., Halkiopoulos, C., \& Arvanitis, D. (2017). Dissemination of environmental soundscape and musical heritage through 3D virtual telepresence. In Book Series: Springer Proceedings in Business and Economics. 3rd International Conference of the International-Associationof-Cultural-and-Digital-Tourism (IACUDiT) on Tourism, Culture and Heritage in Smart Economy Location (pp. 19-34). Athens, Greece. https:// doi.org/10.1007/978-3-319-47732-9_2 
Henriette, E., Feki, M., \& Boughzala, I. (2015). The shape of digital transformation: A systematic literature review. In Ninth Mediterranean Conference on Information Systems (MCIS) 2015 Proceedings. Samos, Greece. Retrieved from http://aisel.aisnet.org/mcis2015\%0Ahttp:// aisel.aisnet.org/mcis2015/10

Hernaus, T., Pejić Bach, M., \& Bosilj Vukšić, V. (2012). Influence of strategic approach to BPM on financial and non-financial performance. Baltic Journal of Management, 7(4), 376-396. https://doi.org/10.1108/17465261211272148 Herzberg, N., \& Kunze, M. (2015). The business process game. In ZEUS (pp. 26-32). Retrieved from ftp://ceur-ws.org/pub/publications/CEUR-WS/ Vol-1360.zip\#page $=31$

Hess, T., Matt, C., Benlian, A., \& Wiesböck, F. (2016). Options for formulating a digital transformation strategy. MIS Quarterly Executive, 15(2), 123-139. Retrieved from http://www.emeraldinsight.com/ doi/10.1108/10878571211209314 https://doi.org/10.7892/boris.105447

Hildebrandt, T. T., Debois, S., Slaats, T., \& Marquard, M. (2017). Managing complexity in process digitalisation with dynamic condition response graphs. In B. Johansson (Ed.), Proceedings of the BIR 2017 pre-BIR Forum, Workshops and Doctoral Consortium co-located with 16th International Conference on Perspectives in Business Informatics Research (BIR 2017) (Vol. 1898). Copenhagen, Denmark. Retrieved from https://pure.itu.dk/ ws/files/83025285/paper16.pdf

Imgrund, F., Fischer, M., Janiesch, C., \& Winkelmann, A. (2018). Approaching digitalization with business process management. In Proceedings of the MKWI, Multikonferenz Wirtschaftsinformatik 2018 (pp. 1725-1736). Lüneburg, Germany. Retrieved from https://www. researchgate.net/profile/Christian_Janiesch/publication/323665985 Approaching_Digitalization_with_Business_Process_Management/ links/5dc2fd7992851c81803321cf/Approaching-Digitalization-withBusiness-Process-Management.pdf

Joubert, P., \& Roodt, S. (2010). The relationship between prior game experience and digital game-based learning: An INNOV8 case-study. In Proceedings of the AIS SIG-ED IAIM 2010 Conference, 25. Retrieved from https://pdfs. semanticscholar.org/8c54/5f58c617942b0635bee673268dee1443baca.pdf

Kane, G. C., Palmer, D., Nguyen Phillips, A., Kiron, D., \& Buckley, N. (2016). Aligning the Organization for Its Digital Future. MIT Sloan Management Review and Deloitte University Press. Retrieved from: https://www2. deloitte.com/content/dam/Deloitte/ie/Documents/Consulting/2016_ MIT_Deloitte-Aligning-Digital-Future.pdf

Kane, G. C., Palmer, D., Philips Nguyen, A., Kiron, D., \& Buckley, N. (2015). Strategy, Not Technology, Drives Digital Transformation. MIT Sloan Management Review and Deloitte University Press. Retrieved from http://www2.deloitte.com/content/dam/Deloitte/cn/Documents/ technology-media-telecommunications/deloitte-cn-tmt-strategy-nottechnology-drive-digital-transformation-en-150930.pdf 
Karla, J., Friedrichs, H.B., \& Braun, D. (2011). A reference model for E-Recruiting addressing the recruiting process of high potentials. In Proceeding of the IADIS International Conference, 81-89.

Kirchmer, M., Franz, P., \& Gusain, R. (2017). Value switch for a digital world: The BPM-D ${ }^{\circledast}$ application. In International Symposium on Business Modeling and Software Design (pp. 148-165). Springer, Cham. https:// doi.org/10.1007/978-3-319-78428-1_8

Kirchmer, M. (2015). The process of process management-mastering the new normal in a digital world. In Business Modeling and Software Development (BMSD) Proceedings, 129-138. Retrieved from https://www. researchgate.net/publication/280018144_THE_PROCESS_OF_PROCESS_ MANAGEMENT_Mastering_the_New_Normal_in_a_Digital_World

Kirkham, T., Wood, S., Winfield, S., Coolin, K., \& Smallwood, A. (2009). An ecosystemfor usercentriclearning:Revolution orevolution? InProceedings of the International Conference on Management of Emergent Digital EcoSystems, (p. 65). ACM. https://doi.org/10.1145/1643823.1643903

Kohlbacher, M., \& Gruenwald, S. (2011). Process orientation:Conceptualization and measurement. Business Process Management Journal, 17(2), 267283. https://doi.org/10.1108/14637151111122347

Kohli, R., \& Johnson, S. (2011). Digital transformation in latecomer industries: CIO and CEO leadership lessons from Encana Oil \& Gas (USA) Inc. MIS Quarterly Executive, 10(4), 141-156. Retrieved from http://search.ebscohost.com/ login.aspx?direct=true\&db=bth\&AN=67793220\&site=ehost-live

Komarov, M., Konovalov, N., \& Kazantsev, N. (2016). how internet of things influences human behavior building social web of services via agentbased approach. Foundations of Computing and Decision Sciences, 41(3), 197-210. https://doi.org/10.1515/fcds-2016-0012

Kontić, L., \& Vidicki, Đ. (2018). Strategy for digital organization: Testing a measurement tool for digital transformation. Strategic Management, 23(1), 29-35. https://doi.org/10.5937/StraMan1801029K

Lederer, M., Betz, S., \& Schmidt, W. (2018). Digital transformation, smart factories, and virtual design: Contributions of subject orientation. In Proceedings of the 10th International Conference on SubjectOriented Business Process Management (p. 10). ACM. https://doi. org/10.1145/3178248.3178256

Lederer, M., Betz, S., Kurz, M., \& Schmidt, W. (2017). Some say digitalizationothers say IT-enabled process management thought through to the end. In Proceedings of the 9th Conference on Subject-oriented Business Process Management (p. 9). ACM. https://doi.org/10.1145/3040565.3040574

Lederer, M., Knapp, J., \& Schott, P. (2017). The digital future has many namesHow business process management drives the digital transformation. In Industrial Technology and Management (ICITM), International Conference on Industrial Technology and Management (pp. 22-26). IEEE. https://doi.org/10.1109/ICITM.2017.7917889 
Leyh, C., Bley, K., \& Seek, S. (2016). Elicitation of processes in business process management in the era of digitization-the same techniques as decades ago? In International Conference on Enterprise Resource Planning Systems (pp. 42-56). Springer, Cham. https://doi.org/10.1007/978-3-319-58801-8_4

Manferdini, A. M. (2012). The use of low-cost technologies for the promotion of cultural heritage sites: The case study of Veleia. In Virtual Systems and Multimedia (VSMM), 2012 18th International Conference on Virtual Systems and Multimedia (pp. 484-490). IEEE. https://doi.org/10.1109/ VSMM.2012.6365962

Manfreda, A. (2017). Is e-government serving companies or vice-versa? In European, Mediterranean, and Middle Eastern Conference on Information Systems (pp. 250-260). Springer, Cham. http://doi.org/10.1007/978-3319-65930-5_21

Market research future (2018, November). Business process management market research report - Global Forecast 2023. Retrieved from https://www.marketresearchfuture.com/reports/business-processmanagement-market-3408

Mathrani, S., Mathrani, A., \& Viehland, D. (2013). Using enterprise systems to realize digital business strategies. Journal of Enterprise Information Management, 26(4), 363-386. https://doi.org/10.1108/JEIM-01-2012-0003

Matt, C., Hess, T., \& Benlian, A. (2015). Digital transformation strategies. Business \& Information Systems Engineering, 57(5), 339-343. https://doi. org/10.1007/s12599-015-0401-5

McDonald, M. (2012, November). Digital strategy does not equal IT strategy. Harvard Business Review. Retrieved from https://hbr.org/2012/11/ digital-strategy-does-not-equa

Müller, O., Schmiedel, T., Gorbacheva, E., \& vom Brocke, J. (2014). Towards a typology of business process management professionals: Identifying patterns of competences through latent semantic analysis. Enterprise Information Systems, 10(1), 50-80. https://doi.org/10.1080/17517575. 2014.923514

Neubauer, M., \& Krenn, F. (2017). Subject-oriented design of smart hyperconnected logistics systems. In Proceedings of the 9th Conference on Subject-oriented Business Process Management (p. 5). ACM. https://doi. org/10.1145/3040565.3040572

Oberhauser, R., Pogolski, C., \& Matic, A. (2018). VR-BPMN: Visualizing BPMN models in virtual reality. In International Symposium on Business Modeling and Software Design (pp. 83-97). Springer, Cham. https://doi. org/10.1007/978-3-319-94214-8_6

Paschek, D., Luminosu, C. T., \& Draghici, A. (2017). Automated business process management-in times of digital transformation using machine learning or artificial intelligence. In MATEC Web of Conferences (Vol. 121, p. 04007). EDP Sciences. https://doi.org/10.1051/matecconf/201712104007

Pejić Bach, M., Spremić, M., \& Suša Vugec, D (2018). Integrating digital transformation strategies into firms: Values, routes and best practice 
examples. In P. Novo Melo \& C. Machado (Eds.), Management and Technological Challenges in the Digital Age (pp. 119-140). Boca Raton FL, USA: CRC Press.

Piccinini, E., Gregory, R. W., \& Kolbe, L. M. (2015). Changes in the producerconsumer relationship-towards digital transformation. 12th International Conference on Wertschaftsinformatik, 1634-1648. Retrieved from https://pdfs.semanticscholar.org/3d4b/954f40e61ad71ab00e6c03b80b b97b66686f.pdf

Queiroz, M. (2017). Mixed results in strategic IT alignment research: a synthesis and empirical study. European Journal of Information Systems, 26(1), 21-36. https://doi.org/10.1057/s41303-016-0024-z

Reijers, H. A. (2006). Implementing BPM systems: The role of process orientation. Business Process Management Journal, 12(4), 389-409. https://doi.org/10.1108/14637150610678041

Reis, J., Amorim, M., Melão, N., \& Matos, P. (2018). Digital transformation: A literature review and guidelines for future research. In Á. Rocha, H. Adeli, L. P. Reis, \& S. Costanzo (Eds.), Trends and Advances in Information Systems and Technologies. WorldCIST'18 2018. Advances in Intelligent Systems and Computing (Vol. 745, pp. 411-421). Springe, Cham. https:// doi.org/10.1007/978-3-319-77703-0 41

Rohner, P. (2013). Identity management for health professionals. Business \& Information Systems Engineering, 5(1), 17-33. https://doi.org/10.1007/ s12599-012-0244-2

Rosemann, M. (2014). Proposals for Future BPM Research Directions. In Proceedings of the 2nd Asia Pacific Business Process Management Conference [Lecture Notes in Business Information Processing] (pp. 1-15). Brisbane: Springer Verlag. https://doi.org/10.1007/978-3-319-08222-6_1

Rosemann, M., \& De Bruin, T. (2005). Towards a business process management maturity model. In D. Bartmann, F. Rajola, J. Kallinikos, D. Avison, R. Winter, P. Ein-Dor, et al. (Eds.), Proceedings of the Thirteenth European Conference on Information Systems, 26-28 May 2005, Germany, Regensburg. Retrieved from https://aisel.aisnet.org/ecis2005/37

Roszkowska, D. (2017). External knowledge sourcing and innovation processes in modern economic environment. International Journal of Management and Economics, 53(2), 39-56. https://doi.org/10.1515/ijme-2017-0011

Sandle, T. (2018, January). Business process management is central to digital transformation. Digital Journal. Retrieved from http://www. digitaljournal.com/business/business-process-management-is-centralto-digital-transformation/article/512404

Schallmo, D., Williams, C. A., \& Boardman, L. (2017). Digital transformation of business models - best practice, enablers, and roadmap. International Journal of Innovation Management, 21(08), 1740014. https://doi. org/10.1142/S136391961740014X

Scheer, A. W., \& Nüttgens, M. (2000). ARIS architecture and reference models for business process management. In W. van der Aalst, J. Desel, \& A. 
Oberweis (Eds.), Business Process Management (pp. 376-389). Springer, Berlin, Heidelberg. https://doi.org/10.1007/3-540-45594-9_24

Schmiedel, T., vom Brocke, J., \& Recker, J. (2013). Which cultural values matter to business process management? Results from a global Delphi study. Business Process Management Journal, 19(2), 292-317. https:// doi.org/10.1108/14637151311308321

Sebastian, I. M., Ross, J. W., Beath, C., Mocker, M., Moloney, K. G., \& Fonstad, N. O. (2017). How big old companies navigate digital transformation. MIS Quarterly Executive. 16(3), 197-213.

Seidel, S., Adams, M., Hofstede, A. H., \& Rosemann, M. (2007). Modelling and supporting processes in creative environments. In $\mathrm{H}$. Oesterle, J. Schelp, \& R. Winter, (Eds.), Proceedings 15th European Conference on Information Systems (pp. 516-527). St. Gallen, Switzerland.

Sienou, A., Lamine, E., Karduck, A. P., \& Pingaud, H. (2008). Towards a semiformal modeling language supporting collaboration between risk and process manager. In Digital Ecosystems and Technologies, 2008. DEST 2008. 2nd IEEE International Conference on (pp. 119-125). IEEE. https:// doi.org/10.1109/DEST.2008.4635179

Singh, A., \& Hess, T. (2017). How chief digital officers promote the digital transformation of their companies. MIS Quarterly Executive, 16(1), 1-17.

Škrinjar, R., Bosilj Vukšić, V., \& Indihar Štemberger, M. (2008). The impact of business process orientation on financial and non-financial performance. Business Process Management Journal, 14(5), 738-754. https://doi. org $/ 10.1108 / 14637150810903084$

Spremić, M. (2017a). Digitalna transformacija poslovanja. Zagreb: Ekonomski fakultet.

Spremić, M. (2017b). Governing digital technology-how mature it governance can help in digital transformation? International Journal of Economics and Management Systems, 2(1), 214-223.

Steinhubl, S. R., \& Topol, E. J. (2015). Moving from digitalization to digitization in cardiovascular care: Why is it important, and what could it mean for patients and providers? Journal of the American College of Cardiology, 66(13), 1489-1496. https://doi.org/10.1016/j.jacc.2015.08.006

Sun, H. B., Chang, Z. Y., Wan, N., \& Mo, R. (2012). Study on key technologies of aero-engine AMRO support system. In Materials Science Forum (Vol. 697, pp. 554-559). Trans Tech Publications. https://doi.org/10.4028/ www.scientific.net/MSF.697-698.554

Tapscott, D. (1997). The Digital Economy: Promise and Peril in The Age of Networked Intelligence. New York: McGraw-Hill.

Terrar, D. (2015, February). What is digital transformation? Retrieved from http://www.theagileelephant.com/what-is-digital-transformation/

Turetken, O., \& Demirors, O. (2011). Plural: A decentralized business process modeling method. Information \& Management, 48(6), 235-247. https:// doi.org/10.1016/j.im.2011.06.001 
Valdez-de-Leon, O. (2016). A digital maturity model for telecommunications service providers. Technology Innovation Management Review, 6(8), 1932. http://doi.org/10.22215/timreview/1008

Van Looy, A. (2017). A quantitative study of the link between business process management and digital innovation. In J. Carmona, G. Engels, \& A. Kumar (Eds.), Business Process Management Forum 2017, LNBIP 297 (pp. 177192). Switzerland: Springer. http://doi.org/10.1007/978-3-319-65015-9_11

Van Looy, A. (2018). On the synergies between business process management and digital innovation. In International Conference on Business Process Management (pp. 359-375). Springer, Cham. https://doi. org/10.1007/978-3-319-98648-7_21

vom Brocke, J., Fay, M., Schmiedel, T., Petry, M., Krause, F., \& Teinzer, T. (2017). A journey of digital innovation and transformation: The case of Hilti. In G. Oswald, \& M. Kleinemeier (Eds.), Shaping the Digital Enterprise: Trends and Use Cases in Digital Innovation and Transformation (pp. 237-251). Berlin: Springer. http://doi.org/10.1007/978-3-319-40967-2_12

vom Brocke, J., Schmiedel, T., Recker, J. C., Trkman, P., Mertens, W., \& Viaene, S. (2014). Ten principles of good business process management. Business Process Management Journal, 20(4), 530-548. http://doi.org/10.1108/ BPMJ-06-2013-0074

Wang, Y., \& Zhang, W. (2012). CAAD education in the panorama of architectural education system: A research on visualisation of the educational tools. In Proceedings of the 17th International Conference on Computer Aided Architectural Design Research (pp. 579-588). Retrieved from http:// papers.cumincad.org/data/works/att/caadria2012_051.content.pdf

Warnecke, D., Gevorkjan, G. D., \& Teuteberg, F. (2018). Amalgamation of 3D printing technology and the digitalized industry-development and evaluation of an open innovation business process model. In International Conference on Business Information Systems (pp. 148-159). Cham: Springer. http://doi.org/10.1007/978-3-319-93931-5_11

Westerman, G., Calméjane, C., Bonnet, D., Ferraris, P., \& McAfee, A. (2011). Digital transformation: a road-map for billion-dollar organizations. Retrieved from https://www.capgemini.com/wp-content/uploads/2017/07/Digital_ Transformation A Road-Map_for_Billion-Dollar_Organizations.pdf

Westerman, G., Tannou, M., Bonnet, D., Ferraris, P., \& McAfee, A. (2012). The digital advantage: How digital leaders outperform their peers in every industry. Retrieved from http://www.capgemini.com/resource-fileaccess/resource/pdf/The_Digital_Advantage__How_Digital_Leaders Outperform_their_Peers_in_Every_Industry.pdf

Zairi, M. (1997). Business process management: A boundaryless approach to modern competitiveness. Business Process Management Journal, 3(1), 64-80. https://doi.org/10.1108/14637159710161585 


\section{Abstrakt}

Zarówno zarzqdzanie procesami biznesowymi, jak i transformacja cyfrowa to obszary, które były przedmiotem zainteresowania zarówno środowiska akademickiego, jak i praktyki. Ponieważ cyfrowa transformacja to tworzenie nowych, innowacyjnych modeli biznesu i/lub zmiana i doskonalenie istniejqcego modelu biznesu za pomoca technologii cyfrowych, można postawić pytanie dotyczqce roli zarzqdzania procesami biznesowymi w transformacji cyfrowej. Aby rzucić na to nieco światła, niniejszy artykuł przedstawia teoretyczne ramy dla obserwacji zwiqzku między zarzqdzaniem procesami biznesowymi a transformacja cyfrowq. Ponadto, podano wyniki obszernego przegladu literatury $i$ analizy w odniesieniu do przedstawionych ram. Wyniki potwierdzajq ważnq rolę zarzqdzania procesami biznesowymi $w$ transformacji cyfrowej. Jednak wyniki wskazuja również na potrzebę dalszych badań i lepszego zrozumienia praktyki. Słowa kluczowe: transformacja cyfrowa, zarzqdzanie procesami biznesowymi, gospodarka cyfrowa, technologia cyfrowa, digitalizacja, digitalizacja, przeglad literatury.

\section{Biographical notes}

Ana-Marija Stjepić, M.A., works as a Teaching and Research assistant at the Department of Informatics at the Faculty of Economics \& Business, University of Zagreb. She graduated with a master's degree in a Business study program "Managerial Informatics" at the Faculty of Economics \& Business, University of Zagreb, where she is currently attending a postgraduate doctoral program. Her research areas include business intelligence systems, business process management, e-business, and digital transformation.

Lucija Ivančić, M.A., is a Ph.D. candidate and a Teaching and Research Assistant of Business Computing, Business Process Management, and Data Management at the Faculty of Economics \& Business, University of Zagreb, at the Department of Informatics. Her current research interests lie in business process modeling and management, IT management, data management, and the intersection of these fields in the era of digital transformation. She received two Dean's awards for papers on discrete-event simulation modeling and information systems auditing. She has published several papers so far.

Dalia Suša Vugec, M.A., is a Teaching and Research Assistant at the Department of Informatics, Faculty of Economics \& Business, University of Zagreb, where she is pursuing her Ph.D. She graduated with a degree in managerial informatics from the Faculty of Economics and Business in Zagreb, where her master's thesis on unified communications earned the Dean's Award for Excellence. Her main research interests are digital literacy, unified communications, business process management, Web services, Web 2.0 technologies, digital transformation, and e-learning. 
